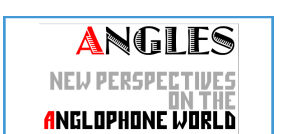

ANELOPHONE WORLI

\title{
Angles
}

New Perspectives on the Anglophone World

11 | 2020

Are You Game?

\section{Play and Games in Fiction and Theory}

\section{Joyce Goggin}

\section{(2) OpenEdition}

\section{Journals}

Electronic version

URL: https://journals.openedition.org/angles/2561

DOI: 10.4000/angles.2561

ISSN: 2274-2042

\section{Publisher}

Société des Anglicistes de l'Enseignement Supérieur

\section{Electronic reference}

Joyce Goggin, "Play and Games in Fiction and Theory", Angles [Online], 11 | 2020, Online since 01

November 2020, connection on 07 June 2022. URL: http://journals.openedition.org/angles/2561 ; DOI: https://doi.org/10.4000/angles.2561

This text was automatically generated on 7 June 2022.

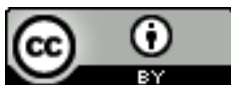

Angles est mise à disposition selon les termes de la Licence Creative Commons Attribution 4.0 International. 


\title{
Play and Games in Fiction and Theory
}

\author{
Joyce Goggin
}

\section{Introduction}

1 There are many reasons to read fictional texts as a kind of play form or game. For example, popular works of fiction disseminated in various in media such as novels, TV series and films, frequently foreground their relationship to games with titles such as Game of Thrones (HBO 2011-2019), The Hunger Games (2012), or Molly's Game (2018). But beyond a survey of titles, there are also more significant reasons for considering fiction and games together. Indeed, the history of literature is replete with examples of fictional texts structured around games, from Boccaccio's Decameron (1353) and Chaucer's Canterbury Tales (1392), to the game of Ombre in Pope's Rape of the Lock (1712), to the preponderance of texts in various forms from print or codex to digital which have been published in the $20^{\text {th }}$ and $21^{\text {st }}$ centuries, and which somehow foreground their "game-ness".

2 In this article, I discuss fiction and games as recounted in literature, including how games structure or articulate plots in specific texts. I will also address how play has been theorized at particular historical junctures. Exploring play and games along with theories of play, I want to illustrate both what paying attention to play and games can do for the study of literature, and more broadly, in the context of our daily lives. ${ }^{1}$

\section{Backstory}

3 As it is widely known, novelist Vladimir Nabokov had much to say about games and literature, having been himself a consummate player of games, from tennis to chess, both of which frequently made their way into his fiction. In a passage from his Lectures on Literature (1980), wherein he discusses games in Jane Austen's Mansfield Park (1814), 
Nabokov is explicit on the point of why an author might include a scene of gameplaying in a fictional text. Here, Nabokov explains that

all talk of marriage is artistically interlinked with the game of cards they are playing, Speculation, and Miss Crawford, as she bids, speculates whether or not she should marry [...]. This re-echoing of the game by her thoughts recalls the same interplay between fiction and reality [...]. Card games form a very pretty pattern in the novel (Nabokov 1980: 40)

In researching play, games, literature, and the work of authors of fiction and criticism who, like Nabokov, are also explicitly concerned with these topics, one soon discovers a sizable critical corpus. In this section, I will touch on some of the seminal texts in that corpus, beginning with Aristotle's Poetics. This is the earliest philosophical work on aesthetics and drama, wherein Aristotle is concerned with imitation or "mimesis", one of several words for "play" in ancient Greek, and this is significant because Aristotle understands the arts as forms or varieties of imitation. For example, mimesis in painting and sculpture gives us representational art that mimics objects in nature; music imitates sounds in the natural world; and the characters in tragedy imitate the noble actions of people in the real world. Mimesis or imitation therefore, as one form of play, is an essential element of poiesis, or the "making" of art, which in turn is instrumental in creating what some now refer to as possible or imaginary worlds, that is, fiction. ${ }^{2}$

5 This traditional understanding of mimesis as an essential element of poiesis places mimetic play at a more distant remove from reality than even the shadows in Plato's famous allegory of the cave from book VII of The Republic. Related in the form of a dialogue between Socrates and Glaucon, book VII allegorizes the human perception of reality, likening our reality to shadows projected on a cave wall. These shadows are perceived by human subjects, shackled around the ankles and neck and unable to turn their heads to see the puppeteers who cast shadows on the cave wall before them, which they mistake for reality. In other words, what mortals see and know is merely shadow, and this is what mimesis mimics - not reality.

Importantly, this version of mimesis and reality has long informed the marginalization or trivialization of mimetic arts as "mere play", "just games", or insignificant ludic imitations of reality. Likewise, the marginalization of play and its rejection as a serious object of study are motivated by the suspicion that play and ludic cultural forms are treacherous and capable of rendering us the dupe. This suspicion of play and imitation, fiction, poiesis or simulacra more generally, has taken hold at various historical junctures since Plato and The Republic, through Emma Bovary's tenuous grip on reality nurtured by cheap novels in Gustave Flaubert's Madame Bovary (1856), to current concerns that players are increasingly susceptible to losing themselves in the fictional worlds of video games, or that events we see on the news are fake. ${ }^{3}$

7 That said, the $18^{\text {th }}$ century marked an important milestone in thinking about play and games, and in taking play seriously in both the philosophical and in the aesthetic sense. A significant moment occurred in Kant's Kritik der Urteilskraft (1790), where he aligns Play with Beauty as a "Ding an sich", that is, as an autotelic entity which contains its own goal or purpose (auto $=$ self + telos $=$ end or goal). In this view, play is thought to be necessarily gratuitous, and therefore "other". Furthermore, as the opposite of work and a hiatus from quotidian drudgery, play is also atemporal, or possessed of its own temporality, as for example a theatre play which may represent a span of decades in 
the space of two hours. Art, as a form of play or mimesis, is therefore theorized as "Purposiveness without purpose" [Zweckmäßigkeit ohne Zweck], hence Art and the Beautiful as forms of play are "other" and elevated, a-historical and therefore transcendental, and distinguished by disinterestedness, either economic or political.

8 At roughly the same time, Schiller wrote On the Aesthetic Education of Man [Über die ästhetische Erziehung des Menschen] (1795), an epistolary philosophical work in which we read that "man plays when he is man in the full sense of the word and he is totally man only when he plays" [... der Mensch spielt nur, wo er in voller Bedeutung des Worts Mensch is, und er ist nur da ganz Mensch, wo er spielt] (Schiller 1967: Letter XV, 64). It is play and only play, he wrote, that makes us complete as human subjects [Das ist gerade Spiel und nur das Spiel, was ihn vollständig macht] (64). If play is indeed such an essential element of what makes us human, or "men" in the fullest sense of the word, it is because of the freedom that play imparts: the freedom to play with ideas without serious consequences, for example. And finally, both Kant and Schiller are also significant in this history of play because their writing made it possible to think about play as more than frivolous or trivial, to salvage it from the category of the "merely" or "only", and to rehabilitate play as the motor of creative thinking and a form of pedagogy. ${ }^{4}$

\section{Homo Ludens and Fiction}

In the service of brevity I now pass over a number of influential $19^{\text {th }}$-century writers who have engaged with the topic of play such as Paul Valéry, Stéphane Mallarmé or Lewis Carroll, in order to pause at Johan Huizinga's Homo Ludens (1938), an ambitious essay on play describing the ludic in the law, art and "Western Civilization" itself (1). In the opening pages, Huizinga outlines his now much-contested, Neo-Kantian definition of play as necessarily "'played out' within certain limits of time and place", such as "[t]he turf, the tennis-court, the chess-board and pavement-hopscotch [which] cannot formally be distinguished from the temple or the magic circle" (20). Play has its own temporality and may be repeated endlessly in games or rituals and, in play, time may be condensed, arrested or advanced. ${ }^{5}$ According to Huizinga, play is also voluntary - it cannot be forced - and is therefore autotelic, having no goal outside itself. Play also transcends other forms of human experience, hence "play is distinct from 'ordinary' life" (20). And finally, play is display: play, as mimesis, always represents something; it is illusion [ilusio $=$ iludere $=$ in play] (11).

10 As a means of illustrating what this history of mimesis and play, up to and including Huizinga, may bring to light in fictional worlds, I will now discuss three examples, beginning with Aldous Huxley's Eyeless in Gaza (1936). The novel is set in England in the period following WWI, with the constant threat of WWII foreshadowed in the text by strange, violent and unpredictable events. This historic moment of terrifying instability is mirrored in the text's disjointed structure, which divides the narrative into randomly-arranged chapters that readers must shift around in their minds as they attempt to reconstruct a linear chronology. When put in order, the chapters comprise the story of central character Anthony Beavis's childhood, beginning in 1902 and covering several decades until he is roughly middle-aged.

11 While there is nothing remarkable about a novel of reminiscences in the modernist period, Eyeless in Gaza is strikingly fragmented, and this feature of the text has been criticized as needlessly jumbled, with some arguing that its central "device of time- 
shifting [is] too mechanical" (Bowering 117; Vitoux 216). I would argue, however, that the text might be more productively read and understood through the lens of theories of play and the logic of games. Such a reading would account for the constant implication that the protagonist's life-world is driven, like a game, by chance and random events, and help to explain the jarring non-chronological ordering of the chapters. Rather than being "needlessly jumbled," it becomes clear that the structure of the narrative articulates the chaos and mounting violence of the period it represents through its insistent refusal of linearity.

More explicitly, the novel is composed of fifty-four chapters, which correspond to the fifty-two cards in a standard deck, plus two jokers or wild cards. This underlying structure then becomes a device for articulating the narrative and indeed, in the opening chapter set in 1933, we find Anthony Beavis sifting through a jumbled pile of photographs from various periods in his life:

Somewhere in the mind a lunatic shuffled a pack of snapshots and dealt them out at random, shuffled once more and dealt them out in different order, again and again, indefinitely. There was no chronology. The idiot remembered no distinction between before and after [...]. Thirty-five years of his conscious life made themselves immediately known to him as chaos - a pack of snapshots in the hands of a lunatic. (Huxley 18)

13 As Pierre Vitoux explains in his essay on Eyeless in Gaza, this passage "describes the structure of the novel [wherein...] the time sequence is completely subverted [...] as if the novelist had shuffled his pack of [...] cards and was now dealing them out [...] as they turn up" (212). In other words, the structure of the text suggests that the novel, like playing cards or the photographs in this scene, may itself be shuffled, with each of the chapters picking up one of several diegetic strands at a different point in the characters' lives, seemingly arranged by chance. It is then the reader as player who becomes implicated in the hermeneutic or interpretive game-structure of the narrative, and who is required to actively keep track of the dates that Huxley provides at the heading of each chapter in order to make sense of the text.

In Nabokov's comments about card games in Mansfield Park to which I referred above, he also makes an explicit connection between games which form "a very pretty pattern in the novel", and which echo the interplay of fiction and reality (Lectures on Literature 40). Similarly, in Nabokov's own novel, Ada or Ardor: A Family Chronicle (1969), the central character Van Veen returns repeatedly in his mind to a castle of cards, which then becomes the organizing principle of both the thesis on time that he is writing, and the narrative frame of the novel as a whole. Veen's Proustian memory centers on the eponymous heroine as a child, building a castle like "a Pompeian Villa with mosaics and paintings inside," which she made from only the court cards in one of her "Grandpa's old gambling packs" (113). So, while Ada herself often recalls the pictorial properties of cards in the narrative, her brother Van remembers his own writing at the heart of the novel in which all of this takes place, as being analogous to that same cardboard villa:

It was Ada's castle of cards. It was the standing of a metaphor on its head not for the sake of the trick's difficulty, but in order to perceive an ascending waterfall or a sunrise in reverse: a triumph, in a sense, over the ardis of time (184-5) which triumphs over the rigidity of chronological time (i.e. "the ardis of time") and creates its own chronotope or time world. And because a castle of cards is, in many ways, literally a playful fictional world or "nulliverse" unto itself, as a metaphor 
embedded in the already ostensibly ludic context of a novel, it communicates the ability of games and fictional worlds to suspend, accordion, or jumble time, as in the example of Eyeless in Gaza (Nabokov 1969: 158).

One further example of a text that foregrounds its own ludicity by placing a fictional game at its centre is Herman Hesse's Glass Bead Game [Das Glasperlenspiel] (1943). Here, I would like to call attention to his notoriously vague description of the game structure at the core of his narrative, for which the novel is named. The glass bead game is described as an immense assemblage of cords with beads that can be moved to indicate positions sent to game masters by written correspondence. The structure, along with the players' activities, comprises

a mode of playing with the total contents and values of our culture [...]. All the insights, noble thoughts, and works of art [...] produced in creative eras, all that subsequent periods of scholarly study have reduced to concepts. [...It is on] this immense body of intellectual values [that] the Glass Bead Game player plays [...]. Theoretically this instrument is capable of reproducing [...] the entire intellectual content of the universe. On the other hand, within this fixed structure [...] a whole universe of possibilities and combinations is available to the individual player. (Hesse 15)

This description calls to mind a Massively Multi-Player On-Line Role Playing Game (MMORPG), albeit a painfully slow one. ${ }^{6}$ More importantly, this passage is suggestive of how ludic fictional worlds are created and might function as possible worlds which interpolate the reader/player in a more lean-forward, active, or Barthesian "writerly" sense than, for example, standard realist prose.

\section{Huizinga's Legacy}

In a lecture to commemorate the $75^{\text {th }}$ anniversary of the publication of Homo Ludens, I discussed the tremendous impact that Huizinga's work has had on the study of literature from the 1960s onwards (Goggin 2014). Interestingly, while Homo Ludens does contain one chapter entitled "Play and Poetry", writing an essay on play and literature was not Huizinga's primary purpose. Homo Ludens has nonetheless inspired much work on literature and ludicity, beginning with Jacques Ehrman's "Homo Ludens Revisited" (1968), W.K. Wimsatt's "Belinda Ludens" on The Rape of the Lock (1973), and Jori Lotman's "The Theme of Card Games in Russian Literature" (1978), as well as more recent work such as Kathleen Blake's study of play and games in Lewis Carroll (Blake 1974), Mihai Spariosu's Literature, Mimesis and Play (1982), Peter Hutchinson's Games Authors Play (1985), Nancy Morrow's Dreadful Games: The Play of Desire and the $19^{\text {th }}$-Century Novel (1988), and David Bell's Circumstances: Chance in the Literary Text (1993).

Moreover, while theoreticians have elucidated the ludic properties of literature, authors of literary texts such as Nabokov may always have been aware of fiction's playful relationship to the world of discourse. As noted above, Nabokov discussed how card games act as a structuring element in the ludic context of fiction in his essays on literature, and he made it a practice to write on index cards. In a 1958 photo shoot for Life Magazine, Nabokov made a point of posing while writing on index cards so as to suggest that he was discovered, as if by chance, in the act of composing a novel. At the same time, while mirroring the importance of chance occurrences in his fiction, the photographs from that session seem to imply that the text he was in the act of writing on index cards could be reshuffled, like a deck of cards, and reassembled in any random 
order to produce a different story. Moreover, given what one reviewer described as Nabokov's "ludic vitality", it is also fitting that Ginko Press published an edition of Pale Fire as a reproduction of the index cards on which he wrote it, and the notes section of the novel separately as a booklet contained in the same box, as though it were instructions for readers who might play their way through the text. This is doubly appropriate given the hybrid form of Pale Fire, as well as its subject, a poet named John Shade who, like Nabokov, composes his poetry on index cards (Harvey 2011).

\section{Interlude}

From the beginning of this essay, I have attempted to trace a trajectory along which one might place theoretical texts on play and games, from Aristotle to Huizinga. One could also construct a timeline of literary texts - ranging from allegorical to realist, from verse to prose - which foreground their ludicity in a variety of ways. ${ }^{7}$ The Decameron and the Canterbury Tales would figure somewhere near the beginning, both texts being composed of discrete episodes embedded in a loose frame narrative, which develops as a characters play at taking turns telling stories. Other texts highlight their ludicity by means of their subject matter, such as The Rape of the Lock (1712), a mockepic about a game of cards. By the close of the $18^{\text {th }}$ century, the publication of board games as extensions or companions to books with which they often shared titles, contributed to "[t]he deliberate blurring of boundaries between board games [and] fictional narratives", encouraging readers "to see games and books as mutuallyconstitutive objects" (Carroll 36). Such texts thus announce their playfulness through a structure which finds both metaphoric and concrete expression in twin games that can be taken apart and manipulated.

21 More recently, one could cite examples from the 1960s, such as texts that ask readers to intervene actively in the progress of the narrative, and manipulate the text physically, such as Marc Saporta's Composition No. 1 (1963) or Nabokov's Pale Fire (1962). Texts in this category fall under the heading of what Espen Aarseth calls 'cybertexts,' or texts that readers and players are required to physically activate and on which they expend non-trivial effort in order to traverse (1). ${ }^{8}$ In other words, such texts require us to do physically what Huxley's Eyeless in Gaza asks readers to do mentally - reshuffle and move segments around - and, I would argue, texts in the former category form a kind of bridge to computer game narratives. Moving even closer to the present, we encounter computer games, from textual adventure games of the 1970s and 1980s, to full-fledged immersive fictional and playable worlds such as World of Warcraft. In the following section then, I will discuss digital game narratives and their place in the genealogy that I have been constructing.

\section{Game on}

In game studies, the historical background and literary associations with play and games as outlined above have been largely neglected, hence "ludology" and game studies seemed to appear suddenly in the early 1990s as a new theory and discipline opposed to literary studies, and specifically to narratology. ${ }^{9}$ Ironically, it was precisely in literature departments and through literary scholars that computer games first received serious academic attention. At the same time, the connection between literary 
fiction and games was noted outside academia, for example by game enthusiast R.V. Kelly, who instinctively explained that he "learned about people who discard real life to inhabit a richer world limited only by imagination [...and] learned what it was like to live inside a novel as it was being written [...]" through video games (11). Likewise, contemporary novelists such as Douglas Coupland, Jeanette Winterson, Chloé Delaume, and numerous fantasy fiction writers produce work which, in some way, openly "remediates" computer games..$^{10}$ In other words, it would appear that the relationship between games and literature is recognised, even if contested, in both games and literature camps.

However, if video games and "commercial" fiction (as opposed to what we might call 'serious literature') are also "play forms", then they do not fit several of the definitions I outlined above, and particularly Huizinga's definition in Homo Ludens, which is based on Kantian concepts such as autotelism and disinterestedness. Indeed, the notion that play needs to be free of economic interest and "no profit can be gained by it" no longer holds in a world where gaming has become a major industry producing a wide variety of contemporary forms of digitized play invested with monetary interest (Homo Ludens 13).

Other aspects of neo-Kantian theories of play that have been challenged or debunked include the idea that play must be gratuitous and, therefore, liberating and fun. As Jesper Juul points out in The Art of Failure (2013), although people commonly think of video games as being "fun," players' facial expressions rarely indicate happiness as they frown and sometimes shout in frustration when they lose, die, or fail to proceed to the next level. Similarly, the attention now paid to the effort and boredom involved in gaming recalls an early essay by Walter Benjamin in which he observed "the likeness of forms of gambling with forms of mechanical labour" whereby "the drudgery of the labourer is [...] a counter part to the drudgery of the gambler" (Cosgrave 121). ${ }^{11}$ Drudgery also describes the labor of thousands of people in developing countries who make their living in so-called "virtual sweatshops", farming and grinding virtual items and currencies for sweatshop wages (Dibbell 2006).

Huizinga further maintains that games and play are always conducted in a magic circle - "the tennis-court, the chess-board" - a notion which no longer holds true, given that pervasive gaming, among other contemporary mobile gaming practices, has expanded the scope of where people play (20). The spread of game play also takes the form of "gamification" or the "game layer on top of the world", as Seth Priebatsch calls it (2010), that is, a ludic web of interfaces connecting us with our world, and increasingly mediating our interaction with various institutions and activities, as well as with each other (see video extract below). For Priebatsch, game interfaces fall into categories, such as appointment keeping, doing things in a specified amount of time, collecting and finding things, and solving puzzles. Although this description of our world is perhaps simplistic, it lays bare our constant interaction with it and with others as being conducted through a patchwork of playful interfaces and gamified activities, which include everything from liking friends' posts on Facebook to collecting enough points to get things for "free", or getting better grades at school.

This media file cannot be displayed. Please refer to the online document http:// journals.openedition.org/angles/2561 
owever, the game layer on top of our world is a continuous interface made up of an endless variety of activities, practices and processes now commonly referred to as "gamification" - if everything has become some form of game - then we must certainly ask, with Bernard Suits (1978) who wrote a book on play, utopia and dystopia, if we have not entered into a particular kind of dystopia where all labor, learning, and punishment - everything, in short - is some kind of game or, in Huizinga's sense, a play form. As Suits explains, in a utopia where everything becomes a game, and wherein all activity is re-defined as play, playing becomes "a very heavy game-playing indeed", with the result that a work-free utopia becomes a playful dystopia (201).

One possible key to working through these issues is suggested in Umberto Eco's essay on Huizinga, published as the introduction to the Italian translation of Homo Ludens (1973). Among many aspects of the text on which Eco comments is Huizinga's etymology of the "play-concept" as expressed in several languages, and the importance of distinguishing between "game" and "play" (Eco xix-xx). Huizinga claims that Western European languages, wherein the verb and noun for play are elided in one compound expression (jouer un jeu, ein Spiel spielen, een spel spelen, jugar un juego), have "succeeded better than others in getting the various aspects of play into one word" (29). As Huizinga further argued, "so-called primitive languages" like Greek often have many words for a given species but not the genus, including words for various manifestations of play; yet they have no single word that expresses play as a unity. This leads him to conclude "that the Greeks [...] failed to perceive the essential playelement" (31) and that the absence of a single word that expresses play as both verb and noun reveals a failure to have achieved a more advanced state of development.

In the case of English, however, Huizinga's thesis breaks down, given that both play and game are common to English, a language that distinguishes between the activity and the object. Huizinga must then conclude that the verb/noun doublet was "lost" in English, and with it, the capacity to express the unique, independent nature of play which lies outside normal categories of action..$^{12}$ The full significance of this seemingly trivial point becomes evident when we see the further extension of Huizinga's logic, which is also informed by the impulse to collapse the distinction between play and games. For example, when discussing "play-structures" such as cultural institutions, which Huizinga also occasionally refers to as games, he proposes to "consider play in its manifold concrete forms as itself a social construction", such as cultural institutions (4). Yet in the first line of Homo Ludens, we also read that "play is older than culture" so that, following Huizinga's logic, social constructions would result from play, rather than play being a social construction. This formulation of play as a social construction requires that we accept the notion that play is part of the things which it transcends, namely, the structure that gives form to play. In other words, for Huizinga, play is simultaneously a "higher unity" and a constituent of structures through which "ordinary life" emerges and which this higher unity transcends - a somewhat logicdefying move.

Perhaps a better model for thinking about play in the present era was proposed by Jacques Derrida in "Structure, Sign and Play" [La structure, le signe et le jeu] (1967). In this essay, Derrida theorized free-play as that which animates "repetitions, substitutions, transformations, and permutations", rather than being concretized in game form (279). His model foregrounds movement rather than binary oppositions or structures, such as Huizinga's magic circle, which presupposes a fixed inside and 
outside. Moreover, because Derrida insists on movement and displacement, his approach to play embodies its own playfulness, so that his account of play is flowing and open-ended as well as being decentered and anticipating no fixed ending. Hence, a play of substitutions and fluidity are built into Derrida's concept so that rather than theorizing play as a game structure and anticipating its end in itself as autotelos, play is indeterminate and characterized by dynamism, volatility and constant decentering, as free-play displaces the concept of a center that might ground or stabilize it, moving through rather than being part of game structures, or formations such as language, literature and other discourses, or institutional structures such as military strategy, economy, or the law.

Importantly, because so much of what has been written on play is rooted in the relationship of play to what is outside of it, studies have been persistently modeled on oppositions such as mimesis/reality, or free play/material interest. In "Playstations. Or, Playing in Earnest" (2005), Steven Connor argues that play is better understood not as transcendental and a-historical, but rather as a concept that bears the stamp of whatever age attempts to grasp its nature. Seen in this way, it is no wonder that Enlightenment philosophers such as Kant and Schiller, writing about play against the backdrop of the industrial and financial revolutions, saw it as the binary opposite of labor and industry, being free of economic interest, transcendental, and autotelic. According to Connor, since the $19^{\text {th }}$ century, play has instead become "a mirror of the growing regulatedness of what Weber would come to call the administered world rather than being an alternative to it" (11). Hence, "[t]he very emptiness or disinterestedness of play might provide the provocation or opportunity to put it to work, or make it earn its living like everything else" (7).

It would seem that this is our current position: we are in a neoliberal world where many are engaged in "playbour" or supposedly fun work such as fan labour for which monetary rewards are few or nonexistent, precisely because play and work have been conflated, while play continues to be, wrongly or not, associated with fun and freedom. ${ }^{13}$ So rather than playful activities such as fiction belonging, however philosophically, to the realm of gratuity and free-spiritedness, perhaps "the realm of play [has been] annexed by the administered world, [and] a certain principle of play [has] been diffused through the system, such that play constitute[s] the rule rather than the exception" (Connor 11).

\section{Conclusion}

Aldous Huxley's grandfather, T.E. Huxley (1825 -1895), once observed that

This universe is [...] like a great game being played out, and we poor mortals are allowed to take a hand. By great good fortune the wiser among us have made out some few of the rules of the game, as at present played. We call them 'Laws of Nature', and honor them because we find that if we obey them we win something for our pains. The cards are our theories and hypotheses, the tricks our experimental verifications. (Aphorism CCXII, qtd. in Gaither 2012: 1554

This quote highlights an implicit point I have been making throughout this article concerning the profundity of games, their connections with ritual and the importance of games in the construction of subjectivity. The playing card deck, which some believe came from the east and evolved from the mystic augury of the tarot, is a good example of this. Cards retain the cosmic associations that resulted in some of the colorful names 
by which they have been known, such as "Bible of the Gypsies", or "Encyclopedia of the Dead". In common lore, it is believed that the fifty-two cards of the pack represent the weeks of the year; that the four suits align with the four seasons; and that the thirteen cards in each suit correspond to the thirteen weeks of each season. In other words, playing cards have a sustained connection with ritual and the greater "mystic game" of life, hence in Eyeless in Gaza the image of a deck of cards becomes a metaphor for the random events that shape and disrupt the protagonist's life, while they also serve as a macro-structuring device for the text.

In this essay, I have touched on a number of theories of mimesis and play, from Aristotle to Derrida, while discussing texts that foreground their similarity to games, in order to discuss how fiction may be productively understood as a kind of mimetic game, and one that also demands interaction from readers. I have also suggested that our lives are increasingly gamified, as is currently visible in places like commercial serialized novels, movies, TV series and video games, as well as in more unexpected places such as banking interfaces and education in the form of MOOGs, as well as entertainment, information production and dissemination, and so on. In turn, the gameness of these platforms, interfaces and institutions, which we are often encouraged to experience as ludic and fun, informs how we conceive of, and interact with, our life worlds.

I would like to conclude, therefore, by considering how subjectivity is rendered in Eyeless in Gaza. Like Van Veen of Nabokov's Ada, who is engaged in writing a philosophical treatise on the nature of time throughout the narrative in which he exists, and which he likens to his sister's house of cards, Anthony Beavis of Eyeless in Gaza is writing Elements of Sociology in which he is concerned with "the individual and his concept of personality" ("December 8, 1926", 111). As I explained at the outset, Eyeless in Gaza begins with Beavis's observation that life is like a pile of snapshots that may be shuffled at will, reordered and reassembled, so that one must make sense not chronologically, "not before the event, but after it, in what had been the future" through the configuration of the great global game being played out as war (Huxley 3 , 19; Vitoux, 19). In this novel, random ordering disrupts readers' expectations of standard chronology, and Beavis comes to the conclusion that "experience is nothing but a formless collection of states, to prop up the notion of a coherent continuity" (Vitoux 2). Or, as D.H. Lawrence wrote in a letter to Huxley, "the individual is unrecognizable, and passes through, as it were, allotropic states", discreet but connected, that one could lay out like playing cards (qtd. in Vitoux 17).

The idea that subjectivity is fluid and devoid of coherence and continuity was associated in Huxley's era with modernism, and currently with postmodernism. This is brilliantly illustrated in Corpus Simsi, Chloé Delaume's fictional account of her life in a MMORPG, where she rewrites Rimbaud's thought-provoking assertion that "I is another" [je est un autre] as "game is another" [jeu est un autre] (Delaume 8). ${ }^{14}$ In other words, subjectivity is a game and is no longer seen as being principally unified. Rather, it now appears that subjectivity is increasingly a question of positions in game structures, and of subjects serving as interchangeable elements in games and rituals rather than modern, individuated beings reassuringly coalesced around a relatively stable subjective core. Virtual Worlds: Real Leaders (2007) in which the company explained why avid video 
gamers are the future of the economy: they are comfortable in simulated worlds; they make decisions quickly; they are not afraid of risk; they believe that management is awarded on a game-by-game basis and is not long term; and they become rapidly immersed and can deal handily with competitive, distributed, virtual environments. So while I have concentrated on the relationship of literature to games and play, given that our life worlds become ever more game-like I believe it has become increasingly urgent to revisit the corpus of work on play and games as a serious, vital topic, in order to examine both our fictional worlds and the ostensibly real, ontological world in which we play and game, and which constructs and contains us as ludic subjects.

\section{BIBLIOGRAPHY}

Aarseth, Espen. Cybertext: Perspectives on Ergodic Literature. Baltimore and London: Johns Hopkins UP, 1997.

Aristotle. Poetics. Trans. Anthony Kenny. Oxford: Oxford UP, 2013.

Bakhtin, Mikhail. The Dialogic Imagination: Four Essays. Austin and London: The U. of Texas P., [1988] 2006.

Bell, David. Circumstances: Chance in the Literary Text. Lincoln: U. of Nebraska P., 1993.

Blake, Kathleen. Play, Games, and Sport: The Literary Works of Lewis Carroll. Ithaca: Cornell UP, 1974.

Bolter, David Jay and Richard Grusin. Remediation: Understanding New Media. Cambridge: MIT

Press, 2000.

Bowering, Peter. Aldous Huxley: A Study of the Major Novels. London: Athlone Press, 1968.

Caillois, Roger. Les jeux et les hommes. Paris: Gallimard, 1958.

Carroll, Siobhan. “'Play you must!': Villette and the $19^{\text {th }}$-century Board Game. Nineteenth-Century Contexts 39:1 (2017): 3-347.

Connor, Steve, "Playstations, or, Playing in Earnest," Static 1 (2005): 1. http:// www.stevenconnor.com/playstations/playstations.pdf

Cosgrave, James F. The Sociology of Risk and Gambling Reader. James F. Cosgrave (ed.). New York: Routledge, 2006.

Delaume, Chloé. Corpus Simsi. Paris: Éditions Léo Sheer, 2003.

Dibbell, Julian. Play Money: Or, How I Quit My Day Job and Made Millions Trading Virtual Loot. New York: Basic Books, 2006.

Derrida, Jacques. Writing and Difference. Trans. Alan Bass. London: Routledge, [1967] 1979.

Dow-Schull, Natasha. Addiction by Design: Machine Gambling in Las Vegas. Princeton: Princeton UP, 2012.

Eco, Umberto. “'Homo Ludens’ Oggi.” In Johan Huizinga. Homo Ludens. Trans. Corina von Schendel. Torino: Giulio Einaudi, 1973. vii-xxvii. 
Ehrmann, Jacques. “Homo Ludens revisited”. Yale French Studies 41 (1968): 31-58.

Gaither, Carl C. Gaither's Dictionary of Scientific Quotations. Eds. Carl C. Gaither and Alma E. CavazosGaither. New York: Springer, 2012.

Goggin, Joyce. The Big Deal: Card Games in 20th-Century Fiction. Unpublished diss. Université de Montréal, 1997.

Goggin, Joyce. "Playbour, Farming and Leisure." Ephemera: Theory and Politics in Organization 11 (4) 2011: 357-368: http://www.ephemerajournal.org/sites/default/files/11-4goggin.pdf

Goggin, Joyce. "Legos and Legacies: Johan Huizinga's Gamified Afterlife.” Games of Late Modernity: Homo Ludens 75 Years Later. International School for Philosophy (ISVW), Leusden, January 15-17, 2014.

Goggin, Joyce. "'How do those Danish bastards sleep at night?': Fan Labour and the Power of Cuteness." Ludic Economies. Eds. Seth Giddings and Alison Harvey. Special issue of The Games and Culture Journal (2018): 1-18.

Harvey, Giles. “'Pale Fire,' the Poem: Does It Stand Alone as a Masterpiece? The New Yorker, December 2, 2011. https://www.newyorker.com/culture/culture-desk/pale-fire-the-poem-doesit-stand-alone-as-a-masterpiece

Hesse, Hermann. The Glass Bead Game. Trans. C. Winston and Richard Winston. New York: Bantam Books, 1980.

Huizinga, Johan. Homo Ludens: A Study of the Play-Element in Culture. Boston: Beacon Press, [1938] 1971.

Hutchinson, Peter. Games Authors Play. New York: Metheun, 1985.

Huxley, Aldous. Eyeless in Gaza. New York: Vintage Books, 2004.

Iser, Wolfgang. Prospecting: From Reader Response to Literary Anthropology. Baltimore: Johns Hopkins UP, 1989.

Juul, Jesper. The Art of Failure: an Essay on the Pain of Playing Video Games. Boston: MIT Press, 2013.

Kant, Immanuel. Kritik der Urteilskraft. Franklin Classics, 2018.

Kelly, R.V. Massively Multiplayer Online Role-Playing Games. Jefferson and London: McFarland, 2004.

Kücklich, Julian. "Precarious Playbour: Modders and the Digital Games Industry". Special issue Precarious Labour. The Fibreculture Journal, 2005. http://five.fibreculturejournal.org/fcj-025-

precarious-playbour-modders-and-the-digital-games-industry/

Lotman, Yuri M. "Theme and Plot: The Theme of Cards and the Card Game in Russian Literature of the Nineteenth Century". PTL: A Journal for Descriptive Poetics and Theory of Literature 3 (1978): 455-492.

Morrow, Nancy. Dreadful Games: The Play of Desire and the $19^{\text {th }}$-Century Novel. Ohio: Kent State UP, 1988.

Murray Janet H. “The Last Word on Ludology v Narratology in Game Studies”. DIGRA conference, 2005. https://www.researchgate.net/publication/

335541373_The_Last_Word_on_Ludology_v_Narratology_in_Game_Studies

https://www.researchgate.net/publication/

335541373_The_Last_Word_on_Ludology_vs_Narratology_in_Game_StudiesNabokov, Vladimir.

Ada or Ardor, A Family Chronicle. London: Weidenfeld and Nicolson, 1969. 
Nabokov, Vladimir. Lectures on Literature. London: Weidenfeld and Nicolson, 1980.

Nabokov, Vladimir. Pale Fire. New York: G.P. Putnam, 1962.

Nagel, Mechthild, Masking the Abject: A Genealogy of Play. London, Boulder, New York, Oxford: Lexington Books, 2002.

Priebatsch, Seth. “The game layer on top of the world.” TEDxBoston, 2010, https://www.ted.com/ talks/seth_priebatsch_the_game_layer_on_top_of_the_world/up-next

Reith, Gerda. The Age of Chance: Gambling in Western Culture. London and New York: Routledge, 1999.

Ricoeur, Paul. Temps et récit I-III. Paris: Éditions du Seuil, 1985.

Ryan, Marie-Laure. "Possible Worlds in Recent Literary Theory”. Style 26 (4) (Winter 1992):

528-553.

Schiller, Friedrich. On the Aesthetic Education of Man: in a Series of Letters. Ed. and Trans. Elizabeth M. Wilkinson and L. A. Willoughby. Oxford: Clarendon Press, 1967.

Spariosu, Mihai. Literature, Mimesis and Play. Tübigen: Gunter Narr Verlag, 1982.

Suits, Bernard. The Grasshopper: Games, Life and Utopia. Toronto: The U. of Toronto P., 1978.

Virtual Worlds, Real Leaders: Online Games Put the Future of Business Leadership on Display. Palo Alto: IBM, 2007.

Vitoux, Pierre. "Structure and Meaning in Aldous Huxley's Eyeless in Gaza”. The Yearbook of English Studies 2 (1972): 212-224.

Wimsatt, W.K. "Belinda Ludens: Strife and Play in The Rape of the Lock". New Literary History 4 (1973): 357-374.

\section{NOTES}

1. I would like to thank the reviewers of this article for their helpful corrections and comments.

2. While the theory of possible worlds is no longer at the cutting edge of literary studies, it continues to have practical application in computer game studies and, outside of academia, it is at the heart of much in popular culture such as much of Scifi and TV series like Westworld. Possible worlds theory may be defined as follows: "The theory of possible worlds-a modern adaptation of a Leibnizian concept-was originally developed as a means to solve problems in formal semantics. In the early seventies, without detectable or at least acknowledged influence from philosophy, French structuralists such as Tzvetan Todorov and Claude Bremond developed an interest in a number of topics which paralleled informally the concepts and concerns of the theory of possible worlds (hence PWT): the mode of existence of narrative events, the importance of virtual elements in literary semantics, and the problem of the possibility of fictional worlds relative to the laws of the real world" (Ryan 528).

3. Various versions of this argument have been made in any number of works cited throughout the present article, but here I am thinking specifically of Mihai Spariosu's Literature, Mimesis and Play: Essays in Literary Theory (1982), particularly chapter one. More recently, Mechthild Nagel has published a detailed study of the history of thinking about play, entitled Masking the Abject: A Genealogy of Play (2002).

4. I have based this section on the original sources and I am much indebted to arguments presented by Spariosu. See also my own unpublished dissertation, The Big Deal: Card Games in $20^{\text {th }}$ Century Fiction, Université de Montréal, 1997. 
5. That fictional texts have their own specific temporality has been discussed by theoreticians from Mikhail Bakhtin (2006: 425) and his notion of the chronotope, to Paul Ricœur and his comprehensive three-volume work on the topic, Temps et récit (1985).

6. MMORPG: Massively Multi-Player On-line Role-Playing Game". MMORPG refers to role-playing games that take place in persistent - i.e. ongoing and 24/7 - fictional worlds, each operated by one server, and played on network-capable platforms such as game consoles, personal computers or mobile devices.

7. Roger Caillois's Les jeux et les hommes (1958) is an essential text for those engaged in identifying genres of fiction that feature games or are constructed like games. Caillois proposes categorizing games under the headings of agon [contest], illinx [vertigo], alea [chance] and mimicry [mimesis], animated by ludus or rational play and paidia or irrational play. While this is not my purpose here, Caillois's text has been influential in literary studies and forms the basis of Peter Hutchinson's Games Authors Play (1985). It also serves as a model for Wolfgang Iser's Prospecting: From Reader Response to Literary Anthropology (1989).

8. "This phenomenon I call ergodic, using a term appropriated from physics that derives from the Greek words ergon and hodos, meaning 'work' and 'path'. In ergodic literature, nontrivial effort is required to allow the reader to traverse the text" (Aarseth 1).

9. The debate between ludology and narratology began in the 1990 s and continued until the early 2000s. See for example, Janet Murray (2005).

10. I borrow the term "remediate" from Bolter and Grusin who define it, in media studies, as a genealogy of how media build on each other and partially supplant each other. Their work on remediation is an examination of "the formal relations within and among media, as well as [...] relations of cultural power and prestige" entailed therein (22).

11. See also Reith (1999), and Dow-Schull (2012).

12. If this logic seems difficult to follow, it is worth noting that Huizinga's editor inserted a footnote at this juncture in the text which reads: "This argument does not occur in the German edition of Huizinga's book, and the presentation of it in his own English version is somewhat obscure. It is hoped that the drift of his argument has been reconstructed without undue distortion" (31).

13. Julian Kücklich's "Precarious Playbour: Modders and the Digital Games Industry" (2005) is one of the very first articles on this topic. On playbour, see also Goggin (2011); on fan labor, see Goggin (2018).

14. This is the famous opening line from a letter that Rimbaud wrote to Paul Demeny on May 15, 1871.

\section{ABSTRACTS}

This article provides an historical overview of various theories of play, games and literature, and examines a number of examples taken from a wide range of texts both theoretical and literary. In doing so, the author analyses specific texts that address the role of play up to the present, and discusses the ludic in relation to mimesis, textuality and literature. The author also discusses fictional narratives on digital platforms such as video games, as well as some of the consequences or ramifications of what is known as the "gamification" the world we currently inhabit. 
Cet article donne un aperçu historique de diverses théories du jeu, des jeux et de la littérature, et examine un certain nombre d'exemples tirés d'un large éventail de textes tant théoriques que littéraires. Ce faisant, l'auteur analyse des textes spécifiques qui traitent du rôle du jeu jusqu'à nos jours, et discute du ludique en relation avec la mimésis, la textualité et la littérature. L'auteur aborde également les récits fictifs sur les plateformes numériques telles que les jeux vidéo, ainsi que certaines des conséquences ou ramifications de ce que l'on appelle la « gamification » du monde dans lequel nous vivons actuellement.

\section{INDEX}

Mots-clés: jeu, mimesis, fiction, littérature, jeux vidéo, ludisme, subjectivité

Keywords: play, games, mimesis, fiction, literature, video games, subjectivity

\section{AUTHOR}

\section{JOYCE GOGGIN}

Joyce Goggin is a Senior Lecturer in literature at the University of Amsterdam, where she also conducts research in film and media studies, as well as on finance and material culture. She has published widely on gambling and finance in literature, painting, film, TV, and computer games. Her most recent publications include Comedy and Crisis: Pieter Langendijk, the Dutch and the Speculative Bubbles of 1720 (Liverpool University Press, 2020), "You are here: The Handmaid's Tale as Graphic Novel," in Adaptation and the Protean Poetics of Margaret Atwood (Palgrave, 2020), "Skyfall and Global Casino Culture," Bond Beyond Bond: Alternative Perspectives on the James Bond Franchise (Amsterdam University Press, 2020), "Framing John Law: G(u)ilt, Fiction, and Finance," in Moralizing Commerce in a Globalizing World Multidisciplinary Approaches to a History of Economic Conscience, 1600-1900 (Oxford UP, 2020), and "The Pro Wrestling Audience as Imagined Community: Reflecting on WWE's Audience as a 'Fan-Generated Narrative' Body," with Argyrios Emmanouloudis, in Convergent Wrestling: Participatory Culture, Transmedia Storytelling, and Intertextuality in the Squared Circle (Routledge, 2019). Contact: j.goggin [at] uva.nl. 